\title{
Determination of Lipid Profile and Anthropometric Measurements of Multiple Sclerosis Patients: A Controlled Descriptive Study
} Multipl Skleroz Hastalarının Yă̆ Profilleri ve Antropometrik Ölçümlerinin Belirlenmesi: Kontrollü Tanımlayıcı Çalışma

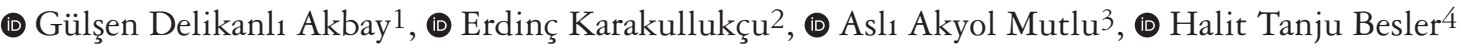 \\ ${ }^{1}$ Karadeniz Technical University Faculty of Health Sciences, Department of Nutrition and Dietetics, Trabzon, Turkey \\ ${ }^{2}$ Karadeniz Technical University Faculty of Science, Department of Statistics and Computer Sciences, Trabzon, Turkey \\ 3 Hacettepe University Faculty of Health Sciences, Department of Nutrition and Dietetics, Ankara, Turkey \\ 4Eastern Mediterranean University Faculty of Health Sciences, Department of Nutrition and Dietetics, Famagusta, Cyprus
}

\begin{abstract}
Objective: Multiple sclerosis (MS) is a neurodegenerative disease of the central nervous system. Lipid profile and anthropometric measurements might differ for patients with MS and healthy people. This study aimed to compare the lipid profiles and anthropometric measurements of patients with MS and healthy participants.

Materials and Methods: The study was designed as a controlled descriptive study, consisting of 392 people (196 patients in the MS-MS group, and 196 healthy volunteers in the control group) who presented to a state hospital in Turkey. Blood samples were collected and lipid profiles (total cholesterol, high-density lipoprotein cholesterol, low-density lipoprotein cholesterol and triglycerides) were analyzed. Body mass index (BMI), waist-to-hip and waist-to-height ratios were calculated, and the parameters were compared between the groups. The relationship between the parameters and the presence of MS was investigated.

Results: The weights, heights, hip circumferences, waist-to-hip and waist-to-height ratios of the people differed statistically significantly between the groups $(\mathrm{p}<0.05)$. There were no statistically significant differences between the groups in terms of the considered lipid profiles. The difference between the BMI values of males in the control and MS groups was statistically significant ( $\mathrm{p}=0.006)$.

Conclusion: The obtained results indicate that anthropometric measurements of patients with MS differ significantly from healthy individuals, although no significant difference could be observed in terms of lipid profiles. Most of the findings of this study are consistent with the literature and suggest that the anthropometric changes in individuals should be followed regularly to prevent a possible MS risk.
\end{abstract}

Keywords: Multiple sclerosis, lipid profile, anthropometric measurement

\section{$\ddot{\mathbf{O} z}$}

Amaç: Multipl skleroz (MS), merkezi sinir sisteminin nörodejeneratif bir hastalığıdır. Yă̆ profili ve antropometrik ölçümler, MS hastaları ve sağlıklı insanlar için farklılık gösterebilmektedir. Bu çalışmada MS hastalarının lipid profilleri ile antropometrik ölçümlerinin sağlıklı bireylerle karşılaştırılması amaçlanmıştır.

Gereç ve Yöntem: Türkiye'deki bir devlet hastanesine başvuran 392 kişiden (MS grubu-196 hasta, kontrol grubu-196 sağlıklı gönüllü birey) oluşan bu çalışma kontrollü tanımlayıcı bir çalışma olarak tasarlanmıştır. Her bir bireyden kan örnekleri toplanmış ve lipid profilleri (toplam kolesterol, yüksek yoğunluklu lipoprotein kolesterol, düşük yoğunluklu lipoprotein kolesterol ve trigliseritler) analiz edilmiştir. Vücut kitle indeksi (VKI), bel-kalça ve bel-boy oranları

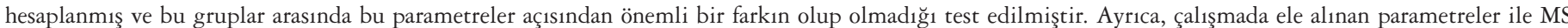
varlığı arasındaki ilişki de araştırılmıştır.

Bulgular: Bireylerin ağırlık, boy, kalça çevresi, bel-kalça ve bel-boy oranları gruplar arasında istatistiksel olarak anlamlı farklılık göstermiştir (p<0,05). Çalışmada ele alınan lipid profilleri açısından gruplar arasında istatistiksel olarak anlamlı bir fark bulunamamıştır. Kontrol grubundaki erkekler ile MS grubundaki erkeklerin VKİ değerleri arasındaki farkın istatistiksel olarak anlamlı olduğu tespit edilmiştir $(\mathrm{p}=0,006)$.

Sonuç: Elde edilen sonuçlar, MS hastalarının antropometrik ölçümlerinin sağlıklı bireylerden önemli ölçüde farklı olduğunu, ancak yă̆ profilleri açısından gruplar arasında anlamlı bir farkın bulunmadığını göstermektedir. Bu çalışmadan elde edilen bulguların çoğu literatürdeki sonuçlarla eşleşmektedir ve olası bir MS riskinden korunmak için bireylerdeki antropometrik değişikliklerin düzenli olarak izlenmesi gerektiğini önermektedir.

Anahtar Kelimeler: Multipl skleroz, yă̆ profili, antropometrik ölçümler

Address for Correspondence/Yazıșma Adresi: Gülșen Delikanlı Akbay PhD, Karadeniz Technical University Faculty of Health Sciences,

Department of Nutrition and Dietetics, Trabzon, Turkey

Phone: +90 4623778836 E-mail: gulsen.delikanli@ktu.edu.tr ORCID: orcid.org/0000-0003-1366-4685

Received/Geliş Tarihi: 05.02.2019 Accepted/Kabul Tarihi: 26.04.2019

${ }^{\circ}$ Copyright 2019 by Turkish Neurological Society

Turkish Journal of Neurology published by Galenos Publishing House. 


\section{Introduction}

The World Health Organization (WHO) defines multiple sclerosis (MS) as a chronic, inflammatory, demyelinating state of the central nervous system (CNS). MS is one of the most common neurologic diseases, there are 2.5 million people known to be affected by MS around the world (1). MS attacks the myelinated axons in the CNS, destroying the myelin and the axons to varying degrees (2). In MS, active leukocytes can pass the blood brain barrier (BBB). The flow of mononuclear cells to the CNS occurs through a deteriorated BBB pathway. The secretion of various inflammatory cytokines and chemokines from glial cells leads to loss of myelin, deterioration of oligodendrocyte integrity, and axonal loss. These events greatly affect progressive neural atrophy (3). The chronic inflammatory processes that characterize MS pathology interfere with immune mechanisms that regulate and confine the inflammatory cascade to prevent irreversible tissue damage (4).

There are different forms of MS. The most common form of the disease is relapsing-remitting MS (RRMS). The more progressive form of MS is secondary progressive MS (PMS), and there is also a primary progressive type of the disease (5). The cause of the disease is unknown, but it appears to involve a combination of genetic susceptibility and a nongenetic triggers, such as a virus, metabolism or environmental factors (6).

The nutritional status of the individual can be evaluated when anthropometric measurements are used constantly and regularly (7). Anthropometry is an indicator of muscle and fat deposition in determining nutritional status. In all patients with chronic illnesses, evaluation of nutritional status is important. If it is performed by trained personnel, it could recognize patients who are at nutritional risk and need detailed nutritional assessment (8). Reports suggest that comprehensive nutritional assessment in patients with MS should be comprise (9) evaluation of nutritional status, which includes medical history (dietary, medical, and medication); physical examinations (anthropometric, body composition measurements, and laboratory tests); calculation of nutritional and energy needs; evaluation of potential dysphagia; scheduling nutritional intake; and planning for the eventual occurrence of complications.

Despite the chronic inflammatory character of MS, it is still unclear if and how lipoprotein levels are altered in patients with MS, and whether changes in feeding habits and body composition influence disease progression. This topic has been investigated in many studies in the literature $(10,11,12,13,14,15,16,17,18)$. Weinstock-Guttman et al. (10) investigated the associations of serum lipid profile variables [triglycerides (TG), high and lowdensity lipoproteins (HDL, LDL), and total cholesterol (TChol)] with disability and magnetic resonance imaging measurements in MS. They found that higher LDL-C and TC and HDL-C levels were associated with more inflammatory activity in patients with MS. Çomoğlu et al. (11) reported that TG and cholesterol levels of patients with MS were higher compared with healthy subjects of similar age and sex. Moreover, mean plasma HDL-C and LDL-C levels of the patients with MS were not statistically different from the healthy controls. Newcombe et al. (12) showed that localized accumulation of LDL and oxidation products in early demyelinating lesions might play a pathogenic role in MS.
The etiology of MS is unknown, but many factors have been associated with its prognosis to date. It is believed that the alteration in the plasma lipid profile may be a causative factor for the progression of MS. The current controlled descriptive study aimed to determine the lipid profile and the anthropometric measurements of patients with MS, and to compare them with healthy subjects. The relationship between the existence of MS and certain parameters was also investigated.

\section{Materials and Methods}

\section{Study Design}

This study was designed as a controlled descriptive study. The output was the presence of MS. Two groups, one including patients having the outcome of interest (MS) and one without it, were compared in terms of the lipid profiles and anthropometric measurements.

\section{Participants}

The study group consisted of patients who presented to a state hospital in Turkey between June 28 $8^{\text {th }}, 2016$, and January $5^{\text {th }}$, 2017. All individuals with the following characteristics were included in the study group: (1) Willing to participate, (2) age between 19 and 65 years, (3) no disease other than MS, (4) no change in eating habits after being diagnosed as having MS. There were 196 patients who met these requirements. In order to constitute the control group, a list of patient names who presented to the internal medicine or the endocrinology outpatient clinics of the hospital in the aforementioned time period was recorded. Among these patients, individuals who were aged 19-65 years and had no chronic health problems were identified and were asked to be a volunteer for the current study. One hundred ninety-six of the patients who accepted to volunteer were randomly selected. These participants were requested to give blood samples when they had no health problems. Thus, the control group was established.

\section{Measurements}

The demographic characteristics and disease histories of the patients with MS were collected through face-to-face interviews using a questionnaire survey. Blood samples were collected for biochemical evaluation and the anthropometric measurements were taken by the researcher.

The body weight, height, waist circumference, mid-upperarm circumference, and hip circumferences were measured. [Body mass index $(\mathrm{BMI})=$ body weight $(\mathrm{kg}) /$ height $\left(\mathrm{m}^{2}\right)$ ], waist-to-hip ratio [waist circumference $(\mathrm{cm}) /$ hip circumference $(\mathrm{cm})$ ] and waist-to-height ratio [waist circumference $(\mathrm{cm}) /$ height $(\mathrm{cm})$ ] were calculated. BMI was grouped as underweight $\left(<18.5 \mathrm{~kg} / \mathrm{m}^{2}\right)$, normal-weight (18.5-24.9 kg/m²), overweight $\left(25-29.9 \mathrm{~kg} / \mathrm{m}^{2}\right)$, and obese $\left(>30 \mathrm{~kg} / \mathrm{m}^{2}\right)$ by using the WHO classification standards (19). Waist-to-hip ratios $(<0.85$ : chronic disease risk is low for females, <0.90: chronic disease risk is low for males) and waist circumferences $(<94 \mathrm{~cm}$ and $<80 \mathrm{~cm}$ are safe levels for females and males, respectively) were classified using WHO standards (20). Waist-to-height ratios were evaluated as "caution" $(<0.4)$, "appropriate" (0.4-0.5), "think of action" (0.5-0.6), and "take action" (>0.6) (21). Lipid profiles (HDL-C, LDL-C, TG, TChol) 
of all individuals were analyzed using an spectrophotometric enzymatic method (22).

\section{Ethical Aspect of the Research}

Approval for the study was obtained from the Ethics Committee of Karadeniz Technical University (decision no: 2016/82). A privacy statement was signed for the patients in the study and permission was received for the use of the patients' data.

\section{Statistical Analysis}

Descriptive statistics were presented in terms of frequencies and percentages. Group statistics were expressed as mean $(\overline{\mathrm{x}}) \pm$ standard deviation (SD). Pearson's chi-square test was used to determine if the presence of MS had a statistically significant relationship with the lipid profile or anthropometric measurements. Depending on whether the Shapiro-Wilk test was significant, the Mann-Whitney U test or Student's t-test was conducted for the main analysis.

All statistical calculations were performed using IBM SPSS Statistics for Windows, version 22.0 (IBM Corp., Armonk, NY, USA). For all tests, the statistical significance level was taken as 0.05 .

\section{Results}

As seen in Table 1, this study consisted of 229 female and 163 male participants. In the control and MS groups, the percentages of female participants were $48.5 \%$ and $68.4 \%$, respectively. The mean age was $39.66 \pm 11.25$ years for the healthy volunteers and $39.09 \pm 10.20$ years for the patients with MS. The average duration of education of the control group (13.14 \pm 3.92 years) was significantly longer than in the MS group ( $9.08 \pm 4.36$ years, $\mathrm{p}<0.001$ ).

For the patients with MS, the disease duration ranged from 6 months to 27 years. The rate of those diagnosed in less than 1 year was $25.5 \%$. The average disease duration for the participants of the MS group was on average $11.36 \pm 5.26$ years.

TChol, TG, and HDL-C levels of the survey participants were within normal ranges. In contrast, the LDL-C values of the samples were higher than the normal range. As shown in Table 2, there were no significant differences between the groups in terms of lipid profiles $(p>0.05)$. These results were confirmed when adjusted for sex.

The anthropometric measurements of all individuals are presented in Table 3. Body weights, heights, hip circumferences, waist-to-hip and waist-to-height ratios were significantly different between the groups $(\mathrm{p}<0.001, \mathrm{p}<0.001, \mathrm{p}<0.001, \mathrm{p}=0.003$, and $\mathrm{p}=0.017$, respectively). When the participants were divided regarding to sex, there were statistically significant differences between the control and MS groups in terms of mid-upper arm circumference, waist-to-hip ratio, and BMI of the males. For females, the measurements that differed between the groups were the hip circumference and waist-to-height ratio. Underweight status was ascribed to $1.5 \%$ of the healthy controls and $4.6 \%$ of the patients with MS. One hundred fifty-five participants were in the normal BMI ranges. Seventy-five healthy controls and 55 patients with MS were overweight. The percentage of obese patients with MS was $25 \%$. As can be seen from Table 4, although the average BMI value of the healthy controls $\left(27.01 \pm 4.98 \mathrm{~kg} / \mathrm{m}^{2}\right)$ was higher than in patients with MS $\left(26.41 \pm 5.28 \mathrm{~kg} / \mathrm{m}^{2}\right)$, this difference was not statistically significant $(\mathrm{p}=0.189)$.

The mean waist-to-hip ratio was $0.90 \pm 0.11$ in healthy controls and $0.87 \pm 0.09$ in patients with MS. The waist-to-hip ratio was less than 0.85 for $37.3 \%$ of women and less than 0.90 for $32.3 \%$ of men in the MS group. As presented in Table 4, 57.6\% of the women and $75.5 \%$ of the men were at chronic disease risk according to the waist-to-hip ratio.

The waist-to-height ratios of the healthy controls $(0.54 \pm 0.09)$ were significantly lower than in patients with MS $(0.56 \pm 0.09)$. Based on the waist-to-height ratios, $26.5 \%$ and $16.8 \%$ of the participants were within the standard range in the control and MS groups, respectively. It can be seen from Table 4 that $45.7 \%$ of the total participants should be aware of the fact that they were on the verge of obesity, and $29.1 \%$ should take action against android obesity.

In order to investigate a possible relationship between the presence of MS and the considered anthropometric measurements, categorical variables were converted into dichotomous variables by using some threshold values. It can be seen in Table 5 that 104 of the 196 patients with MS had a BMI higher than $25 \mathrm{~kg} /$ $\mathrm{m}^{2}$. Only $38.3 \%$ of the healthy subjects had a BMI less than 25 $\mathrm{kg} / \mathrm{m}^{2}$. Among 225 individuals with a BMI of $\geq 25 \mathrm{~kg} / \mathrm{m}^{2}$, the percentage of individuals with MS was $53.1 \%$. On the other hand, $46.9 \%$ of 167 individuals were patients with MS with a BMI of $<25 \mathrm{~kg} / \mathrm{m}^{2}$. The existence of MS had no statistically significant relationship with BMI $(\mathrm{p}=0.082)$. In terms of waist-to-hip circumference ratio, in the study and control groups, there were equal number of individuals whose measurements were greater than or equal to 0.8 . Based on this, no significant relationship could be detected between the waist-to-hip ratio and the presence of MS ( $>0.05)$. Nevertheless, cross-table analysis revealed a significant relationship between the presence of MS and the waistto-height ratio $(\mathrm{p}=0.045) ; 66.3 \%$ of 196 patients with MS had a waist-to-height ratio less than 0.6. Among 278 individuals with a waist-to-height ratio value of $<0.6$, the percentage of individuals with MS was $66.3 \%$. Of the 196 healthy individuals, $75.5 \%$ had a waist-to-height ratio less than 0.6.

Table 1. Demographic characteristics of the survey individuals

\section{Females $(n=229)$}

\section{Variable}

Age (years)

( $n=95)$

38.0

MS $(n=134)$

Mean \pm SD Median

Education (years)

$13.6 \pm 4.4$

14.0

SD: Standard deviation, MS: Multiple sclerosis

Males $(n=163)$

Control $(n=101) \quad$ MS $(n=62)$

\begin{tabular}{|c|c|c|c|c|c|}
\hline \multirow[b]{2}{*}{ MS $(n=134)$} & \multirow[b]{3}{*}{ Median } & \multicolumn{3}{|c|}{ Males $(n=163)$} & \multirow[b]{3}{*}{ Median } \\
\hline & & \multicolumn{2}{|c|}{ Control $(n=101)$} & MS $(n=62)$ & \\
\hline Mean \pm SD & & Mean \pm SD & Median & Mean \pm SD & \\
\hline $38.6 \pm 10.1$ & 39.0 & $41.2 \pm 11.9$ & 42.0 & $40.2 \pm 10.3$ & 38.5 \\
\hline $8.8 \pm 4.6$ & 8.0 & $12.8 \pm 3.5$ & 13.0 & $9.7 \pm 3.9$ & 11.0 \\
\hline
\end{tabular}




\section{Discussion}

\section{Summary of Main Findings}

Studies in the literature are generally based on either the biochemical information or the anthropometric measurements of patients with MS, regardless of the parameters affecting the existence of disease. The current study focused on designating the lipid profile and the anthropometric measurements of patients with MS and identifying the relationship between the disease and these parameters.

\begin{tabular}{|c|c|c|c|c|c|c|}
\hline Variable & Sex & Group & Mean & SD & Median & $\mathrm{p}$ \\
\hline \multirow{9}{*}{$\mathrm{TG},(\mathrm{mg} / \mathrm{dL})$} & \multirow{3}{*}{ Female } & Control & 111.6 & 66.7 & 101.0 & \multirow{3}{*}{0.163} \\
\hline & & MS & 123.3 & 69.7 & 104.5 & \\
\hline & & Total & 118.5 & 68.6 & 101.0 & \\
\hline & \multirow{3}{*}{ Male } & Control & 159.9 & 98.3 & 144.0 & \multirow{3}{*}{0.828} \\
\hline & & MS & 163.7 & 115.9 & 128.0 & \\
\hline & & Total & 161.4 & 105.0 & 140.0 & \\
\hline & \multirow{3}{*}{ Total } & Control & 136.5 & 87.7 & 113.0 & \multirow{3}{*}{0.936} \\
\hline & & MS & 136.1 & 88.7 & 112.5 & \\
\hline & & Total & 136.3 & 88.1 & 112.5 & \\
\hline \multirow{9}{*}{ TChol, (mg/dL) } & \multirow{3}{*}{ Female } & Control & 190.6 & 45.2 & 185.0 & \multirow{3}{*}{0.764} \\
\hline & & MS & 191.3 & 42.1 & 187.0 & \\
\hline & & Total & 191.0 & 43.3 & 186.0 & \\
\hline & \multirow{3}{*}{ Male } & Control & 196.3 & 40.6 & 194.0 & \multirow{3}{*}{$0.882^{\mathrm{a}}$} \\
\hline & & MS & 197.3 & 43.8 & 200.0 & \\
\hline & & Total & 196.7 & 41.7 & 195.0 & \\
\hline & \multirow{3}{*}{ Total } & Control & 193.6 & 42.9 & 189.5 & \multirow{3}{*}{0.855} \\
\hline & & MS & 193.2 & 42.6 & 187.5 & \\
\hline & & Total & 193.4 & 42.7 & 189.0 & \\
\hline \multirow{9}{*}{ LDL-C, (mg/dL) } & \multirow{3}{*}{ Female } & Control & 111.2 & 29.4 & 108.0 & \multirow{3}{*}{0.200} \\
\hline & & MS & 119.1 & 38.9 & 110.0 & \\
\hline & & Total & 115.8 & 35.4 & 108.0 & \\
\hline & \multirow{3}{*}{ Male } & Control & 121.2 & 36.5 & 120.0 & \multirow{3}{*}{$0.483^{\mathrm{a}}$} \\
\hline & & MS & 125.6 & 41.1 & 125.5 & \\
\hline & & Total & 122.9 & 38.3 & 120.0 & \\
\hline & \multirow{3}{*}{ Total } & Control & 116.4 & 33.6 & 114.0 & \multirow{3}{*}{0.362} \\
\hline & & MS & 121.1 & 39.6 & 117.0 & \\
\hline & & Total & 118.7 & 36.7 & 115.3 & \\
\hline \multirow{9}{*}{ HDL-C, $(\mathrm{mg} / \mathrm{dL})$} & \multirow{3}{*}{ Female } & Control & 54.2 & 12.0 & 54.0 & \multirow{3}{*}{0.082} \\
\hline & & MS & 51.5 & 12.3 & 51.0 & \\
\hline & & Total & 52.6 & 12.2 & 52.0 & \\
\hline & \multirow{3}{*}{ Male } & Control & 46.3 & 12.7 & 45.0 & \multirow{3}{*}{0.121} \\
\hline & & MS & 43.3 & 8.7 & 41.0 & \\
\hline & & Total & 45.2 & 11.5 & 44.0 & \\
\hline & \multirow{3}{*}{ Total } & Control & 50.1 & 12.9 & 50.0 & \\
\hline & & MS & 48.9 & 11.9 & 47.0 & 0.303 \\
\hline & & Total & 49.5 & 12.4 & 48.3 & \\
\hline
\end{tabular}




\begin{tabular}{|c|c|c|c|c|c|c|}
\hline Variables & & Group & Mean & SD & Median & $\mathrm{p}$ \\
\hline \multirow{9}{*}{ Body weight (kg) } & \multirow{3}{*}{ Female } & Control & 68.60 & 13.59 & 65.00 & \multirow{3}{*}{0.903} \\
\hline & & MS & 67.89 & 13.44 & 67.50 & \\
\hline & & Total & 68.18 & 13.48 & 67.00 & \\
\hline & \multirow{3}{*}{ Male } & Control & 85.63 & 13.91 & 85.00 & \multirow{3}{*}{$0.001^{\mathrm{a} *}$} \\
\hline & & MS & 77.93 & 12.75 & 77.00 & \\
\hline & & Total & 82.70 & 13.95 & 81.00 & \\
\hline & \multirow{3}{*}{ Total } & Control & 77.37 & 16.16 & 76.00 & \multirow{3}{*}{$<0.001^{*}$} \\
\hline & & MS & 71.07 & 14.00 & 72.00 & \\
\hline & & Total & 74.22 & 15.42 & 75.00 & \\
\hline \multirow{9}{*}{ Height (m) } & \multirow{3}{*}{ Female } & Control & 1.62 & 0.06 & 1.63 & \multirow{3}{*}{$0.005 *$} \\
\hline & & MS & 1.60 & 0.07 & 1.60 & \\
\hline & & Total & 1.61 & 0.07 & 1.60 & \\
\hline & \multirow{3}{*}{ Male } & Control & 1.76 & 0.09 & 1.75 & \multirow{3}{*}{0.372} \\
\hline & & MS & 1.73 & 0.07 & 1.73 & \\
\hline & & Total & 1.75 & 0.09 & 1.73 & \\
\hline & \multirow{3}{*}{ Total } & Control & 1.69 & 0.10 & 1.68 & \multirow{3}{*}{$<0.001^{*}$} \\
\hline & & MS & 1.64 & 0.09 & 1.63 & \\
\hline & & Total & 1.67 & 0.10 & 1.66 & \\
\hline \multirow{9}{*}{$\begin{array}{l}\text { Mid-upper arm } \\
\text { circumference }\end{array}$} & \multirow{3}{*}{ Female } & Control & 29.23 & 4.21 & 28.00 & \multirow{3}{*}{0.067} \\
\hline & & MS & 29.91 & 3.72 & 30.00 & \\
\hline & & Total & 29.63 & 3.94 & 29.00 & \\
\hline & \multirow{3}{*}{ Male } & Control & 33.24 & 3.88 & 33.00 & \multirow{3}{*}{$0.001 *$} \\
\hline & & MS & 31.16 & 2.73 & 31.00 & \\
\hline & & Total & 32.45 & 3.62 & 32.00 & \\
\hline & \multirow{3}{*}{ Total } & Control & 31.29 & 4.51 & 31.00 & \multirow{3}{*}{0.068} \\
\hline & & MS & 30.31 & 3.48 & 30.00 & \\
\hline & & Total & 30.80 & 4.05 & 30.00 & \\
\hline \multirow{9}{*}{$\begin{array}{l}\text { Hip } \\
\text { circumference } \\
(\mathrm{cm})\end{array}$} & \multirow{3}{*}{ Female } & Control & 102.05 & 12.67 & 100.00 & \\
\hline & & MS & 106.04 & 10.47 & 105.00 & $0.002 *$ \\
\hline & & Total & 104.39 & 11.57 & 103.00 & \\
\hline & & Control & 101.89 & 12.51 & 103.00 & \\
\hline & Male & MS & 104.31 & 8.65 & 103.00 & 0.216 \\
\hline & & Total & 102.81 & 11.23 & 103.00 & \\
\hline & & Control & 101.97 & 12.55 & 101.00 & \\
\hline & Total & MS & 105.49 & 9.94 & 105.00 & $0.001^{*}$ \\
\hline & & Total & 103.73 & 11.44 & 103.00 & \\
\hline & & Control & 0.85 & 0.10 & 0.85 & \\
\hline & Female & MS & 0.86 & 0.09 & 0.87 & 0.328 \\
\hline & & Total & 0.85 & 0.10 & 0.86 & \\
\hline & & Control & 0.96 & 0.08 & 0.95 & \\
\hline Waist-to-hip ratio & Male & MS & 0.92 & 0.07 & 0.93 & $0.001^{*}$ \\
\hline & & Total & 0.94 & 0.08 & 0.94 & \\
\hline & & Control & 0.90 & 0.11 & 0.91 & \\
\hline & Total & MS & 0.87 & 0.09 & 0.89 & $0.001^{*}$ \\
\hline & & Total & 0.89 & 0.10 & 0.90 & \\
\hline
\end{tabular}




\begin{tabular}{|c|c|c|c|c|c|c|}
\hline \multicolumn{7}{|c|}{ Table 3. Continued } \\
\hline Variables & & Group & Mean & SD & Median & $\mathrm{p}$ \\
\hline \multirow{9}{*}{$\begin{array}{l}\text { Waist-to-height } \\
\text { ratio }\end{array}$} & \multirow{3}{*}{ Female } & Control & 0.54 & 0.10 & 0.52 & \multirow{3}{*}{$0.004 *$} \\
\hline & & MS & 0.57 & 0.10 & 0.56 & \\
\hline & & Total & 0.56 & 0.10 & 0.54 & \\
\hline & \multirow{3}{*}{ Male } & Control & 0.55 & 0.07 & 0.55 & \multirow{3}{*}{0.921} \\
\hline & & MS & 0.55 & 0.07 & 0.54 & \\
\hline & & Total & 0.55 & 0.07 & 0.54 & \\
\hline & \multirow{3}{*}{ Total } & Control & 0.54 & 0.09 & 0.53 & \multirow{3}{*}{$0.017^{*}$} \\
\hline & & MS & 0.56 & 0.09 & 0.55 & \\
\hline & & Total & 0.55 & 0.09 & 0.54 & \\
\hline \multirow{9}{*}{ BMI $\left(\mathrm{kg} / \mathrm{m}^{2}\right)$} & \multirow{3}{*}{ Female } & Control & 26.23 & 5.42 & 25.28 & \multirow{3}{*}{0.514} \\
\hline & & MS & 26.63 & 5.78 & 25.46 & \\
\hline & & Total & 26.47 & 5.62 & 25.39 & \\
\hline & \multirow{3}{*}{ Male } & Control & 27.74 & 4.43 & 26.79 & \multirow{3}{*}{$0.006^{*}$} \\
\hline & & MS & 25.93 & 4.00 & 24.97 & \\
\hline & & Total & 27.05 & 4.35 & 26.03 & \\
\hline & \multirow{3}{*}{ Total } & Control & 27.01 & 4.98 & 26.11 & \multirow{3}{*}{0.189} \\
\hline & & MS & 26.41 & 5.28 & 25.39 & \\
\hline & & Total & 26.71 & 5.13 & 25.81 & \\
\hline
\end{tabular}

Even though statistics do not always show the facts, it is believed that under appropriate circumstances, unbiased and sufficient sample selection can lead researchers to the best information about the facts. In this respect, we conducted a large-scale literature search, and efforts were made to increase the validity of the obtained statistics of the current study. MS-based studies in literature were compared in terms of lipid profiles and anthropometric measurements, and the findings of the studies are presented in Table 6 and Table 7, respectively.

Some studies in the literature argue that lipid profiles should show changes in patients with MS. Quintana et al. (13) discussed the use of lipids and the antibody response against them as biomarkers for MS. Jorissen et al. (14) determined whether lipoprotein levels and HDL function were altered in patients with MS. Their data showed that patients with RRMS had lower total LDL compared with healthy controls and with patients with PMS, as a result of the reduced number of large LDL particles. Moreover, in a subgroup of patients with RRMS with a low BMI $(B M I \leq 23$ $\mathrm{kg} / \mathrm{m}^{2}$ ), a higher level of small HDL particles and increased levels of TG were observed as in the study of Palavra et al. (15) who observed an increase in small HDL particles and TG in the total RRMS patient population. Weinstock-Guttman et al. (10) showed that MS clinical progression was associated with higher baseline TC and LDL-C levels, and higher HDL-C levels were associated with lesser radiologic disease activity. Despite these findings, there are some studies showing contradictory results with regard to the alterations in lipoprotein levels of patients with MS. According to the study of Navarro and Segura (16), the mean concentrations of plasma TChol, HDL-C, and total TG were in the normal range for both the MS and control groups. There were no significant differences between these groups. Similar results were observed in the study of Çomoğlu et al. (11). Mean plasma TChol levels were slightly higher in patients with MS than in healthy volunteers, but this was not significant. The mean plasma HDL-C and LDL-C levels of patients with MS were not statistically different from the values of the controls. Dogan (17) evaluated the effect of lipoprotein-associated phospholipase A2 (Lp-PLA2) activity and serum lipids in patients with MS. Their findings revealed that the serum lipid concentrations and Lp-PLA2 activity had no significant effect on MS and its progression. There were no statistically significant differences between patients with MS and healthy controls in terms of Lp-PLA2 activity, TChol, TG, HDL-C, LDL-C, atherogenic index of plasma (AIP), non-HDL-C and TChol to HDL-C ratio.

In our present study, findings related to lipid profiles showed that there was no statistically significant difference between the lipid profiles of patients in the MS group and healthy subjects. This result did not change when the groups were compared after adjusting for sex. The boxplots in Figure 1 graphically depict groups of numeric data through their quartiles. In terms of TG, TChol, and LDL, Jorissen et al. (14) and Çomoğlu et al. (11) found similar results supporting the findings of the present study. Taking into consideration that the study groups in the compared literature come from variety of different nations, have different genetic features and nutritional status, and are exposed to different environmental factors, it is likely to observe differences among the studies. As stated in the study of Weinstock-Guttman et al. (10), lifestyle changes including adoption of a healthier diet and 
regular exercise in order to improve the serum lipid profile may be beneficial for patients with MS to improve their neurologic condition.

Table 4. Anthropometric measurements of the participants based on the World Health Organization classification

\begin{tabular}{|c|c|c|c|c|c|c|c|}
\hline \multirow{2}{*}{$\begin{array}{l}\text { Group } \\
\text { Variables }\end{array}$} & \multicolumn{2}{|c|}{$\begin{array}{l}\text { Control } \\
(n=196)\end{array}$} & \multicolumn{2}{|c|}{$\begin{array}{l}\text { MS } \\
(n=196)\end{array}$} & \multicolumn{2}{|c|}{$\begin{array}{l}\text { Total } \\
(n=392)\end{array}$} & \multirow[t]{2}{*}{$\mathrm{p}$} \\
\hline & $\mathrm{n}$ & $\%$ & $\mathrm{n}$ & $\%$ & $\mathrm{n}$ & $\%$ & \\
\hline \multicolumn{8}{|c|}{ BMI $\left(\mathrm{kg} / \mathrm{m}^{2}\right)$} \\
\hline$<18.5$ & 3 & 1.5 & 9 & 4.6 & 12 & 3.1 & \multirow{5}{*}{0.189} \\
\hline $\begin{array}{l}\geq 18.5 \text { and } \\
<24.99\end{array}$ & 72 & 36.7 & 83 & 42.3 & 155 & 39.5 & \\
\hline $\begin{array}{l}\geq 25 \text { and } \\
<29.99\end{array}$ & 75 & 38.3 & 55 & 28.1 & 130 & 33.2 & \\
\hline$\geq 30$ & 46 & 23.5 & 49 & 25.0 & 95 & 24.2 & \\
\hline$\overline{\mathrm{X}} \pm \mathrm{SD}$ & \multicolumn{2}{|c|}{$27.01 \pm 4.98$} & \multicolumn{2}{|c|}{$26.41 \pm 5.28$} & \multicolumn{2}{|c|}{$26.71 \pm 5.13$} & \\
\hline \multicolumn{8}{|c|}{ Waist-to-hip ratio } \\
\hline \multicolumn{8}{|l|}{ Female } \\
\hline$<0.85$ & 47 & 49.5 & 50 & 37.3 & 97 & 42.4 & \multirow{6}{*}{0.003} \\
\hline$\geq 0.85$ & 48 & 50.5 & 84 & 62.7 & 132 & 57.6 & \\
\hline Male & & & & & & & \\
\hline$<0.90$ & 20 & 19.8 & 20 & 32.3 & 40 & 24.5 & \\
\hline$\geq 0.90$ & 81 & 80.2 & 42 & 67.7 & 123 & 75.5 & \\
\hline$\overline{\mathrm{X}} \pm \mathrm{SD}$ & \multicolumn{2}{|c|}{$0.90 \pm 0.11$} & \multicolumn{2}{|c|}{$0.87 \pm 0.09$} & \multicolumn{2}{|c|}{$0.89 \pm 0.10$} & \\
\hline \multicolumn{8}{|c|}{ Waist-to-height ratio } \\
\hline$<0.4$ & 6 & 3.1 & 8 & 4.1 & 14 & 3.6 & \\
\hline $\begin{array}{l}\geq 0.4 \text { and } \\
<0.5\end{array}$ & 52 & 26.5 & 33 & 16.8 & 85 & 21.7 & \multirow{4}{*}{$0.017^{*}$} \\
\hline $\begin{array}{l}\geq 0.5 \text { and } \\
<0.6\end{array}$ & 90 & 45.9 & 89 & 45.4 & 179 & 45.7 & \\
\hline$\geq 0.6$ & 48 & 24.5 & 66 & 33.7 & 114 & 29.1 & \\
\hline$\overline{\mathrm{X}} \pm \mathrm{SD}$ & \multicolumn{2}{|c|}{$0.54 \pm 0.09$} & \multicolumn{2}{|c|}{$0.56 \pm 0.09$} & \multicolumn{2}{|c|}{$0.55 \pm 0.09$} & \\
\hline
\end{tabular}

Table 5. Evaluation of multiple sclerosis existence with some anthropometric measurements of the survey samples $(\mathrm{n}=392)$

\begin{tabular}{|c|c|c|c|c|c|c|c|c|}
\hline \multirow{2}{*}{$\begin{array}{l}\text { Group } \\
\text { Variables }\end{array}$} & & \multicolumn{2}{|c|}{ Control } & \multicolumn{2}{|l|}{ MS } & \multicolumn{2}{|c|}{ Total } & \multirow[t]{2}{*}{$\mathrm{p}$} \\
\hline & & $\mathrm{n}$ & $\%$ & $\mathrm{n}$ & $\%$ & $\mathrm{n}$ & $\%$ & \\
\hline \multirow{2}{*}{$\begin{array}{l}\text { Waist-to- } \\
\text { hip ratio }\end{array}$} & $<0.8$ & 34 & 17.3 & 34 & 17.3 & 68 & 17.3 & \multirow{2}{*}{0.999} \\
\hline & $\geq 0.8$ & 162 & 82.7 & 162 & 82.7 & 324 & 82.7 & \\
\hline \multirow{2}{*}{$\begin{array}{l}\text { Waist-to- } \\
\text { height ratio }\end{array}$} & $<0.6$ & 148 & 75.5 & 130 & 66.3 & 278 & 70.9 & \multirow{2}{*}{$0.045 *$} \\
\hline & $\geq 0.6$ & 48 & 24.5 & 66 & 33.7 & 114 & 29.1 & \\
\hline \multirow{2}{*}{$\begin{array}{l}\text { BMI } \\
\left(\mathrm{kg} / \mathrm{m}^{2}\right)\end{array}$} & $<25$ & 75 & 38.3 & 92 & 46.9 & 167 & 42.6 & \multirow{2}{*}{0.082} \\
\hline & $\geq 25$ & 121 & 61.7 & 104 & 53.1 & 225 & 57.4 & \\
\hline
\end{tabular}

Patients with MS are expected to face weight reduction due to the presence of hypermetabolism, decreased physical activity, and a possible obstacle in the process of preparing and cooking food. It is also believed that inflammation in chronic illnesses is generally related with the alteration in body composition including weight loss (23). Moreover, height measures thought to be affected by genetic, physical, and nutritional differences that might have associations with MS. Due to these facts, a significant difference between the anthropometric characteristics of healthy participants and patients with MS was predicted to be found in this study. As expected, healthy controls had significantly higher body weights and body heights than patients with MS ( $<<0.001)$. In accordance with our results, the body weights and heights of patients with MS were lower than controls in the studies of Ozgocmen et al. (24) and Ghadirian et al. (25).

As an anthropometric measurement, BMI has been the most commonly investigated measure due to its presumed association with MS. In a study (25) performed in Montreal between 1992 and 1995, the mean age, weight, and height of 197 incident cases and 202 frequency-matched controls were compared, and no statistically significant differences were found. The case patients had a significantly lower BMI than the controls. An inverse association was observed between high $\mathrm{BMI}$ and the risk of MS, with an odds ratio of 0.76 . In the study of Formica et al. (26), 71 female patients with MS were compared with 71 healthy, age-comparable female controls ( $45.6 \pm 1.1$ vs. $47.7 \pm 1.2$ years). The BMI in patients with MS was found to be statistically less than the BMI of controls $\left(23.6 \pm 0.6\right.$ vs. $\left.26.0 \pm 1.0 \mathrm{~kg} / \mathrm{m}^{2}, \mathrm{p}<0.05\right)$. In a prospective study of over 230,000 women in the United States, being obese in late adolescence/early adulthood (age 18 years) was associated with a 2-fold increased risk of MS (27). In their cross-sectional cohort study linking electronic medical record information to a mailed survey from 1999 to 2004, Khurana et al. (28) reported an increased prevalence of overweight and obesity in a large sample of older veterans with MS (mean age: $59.6 \pm 11.9$ years),

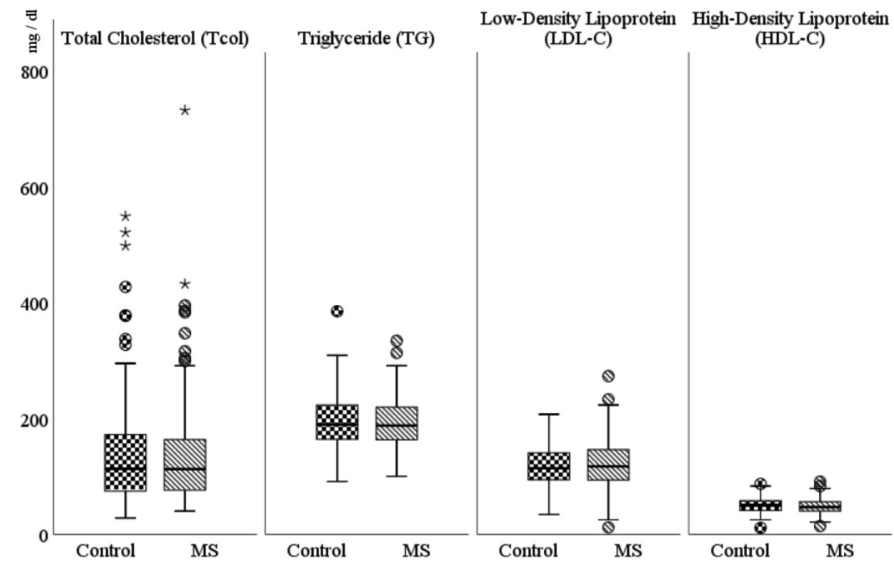

Figure 1. Comparison of the lipid profiles of the participants in the control and multiple sclerosis groups. No statistically significant difference was found in terms of all lipid profiles (each p $>0.05$ )

TChol: Total cholesterol, TG: Triglyceride, LDL-C: Low-density lipoprotein-cholesterol, HDL-C: High-density lipoprotein-cholesterol, MS: Multiple sclerosis 
predominantly males $(86.7 \%)$. According to the findings of a population-based case-control study conducted in Sweden, patients with MS $(\mathrm{n}=1571)$ with a BMI over $27 \mathrm{~kg} / \mathrm{m}^{2}$ at the age of 20 years had a two-fold greater risk of developing MS compared with normal-weight subjects (29). In the prospective study performed by Munger et al. (30) on Danish school children, it was concluded that higher BMI during childhood and early adolescence was associated with an increased risk of MS. Among boys, the association was weaker than for girls, and overall not significant. Although, all these studies suggested a link between obesity and an increased risk of MS, the validity of the findings of these studies were questioned by some experts due to the bias related to the study designs. These studies were generally unable to account for other confounding factors that could have an impact on the results.

Recently, in a Canadian study conducted to investigate the possible causal link between obesity and MS, Mokry et al. (31) used a Mandelian randomization approach, which involved the use of genetic variants as instrumental variables to measure exposures to a risk factor on an outcome. These results of the study provided evidence that genetically elevated BMI was strongly associated with an increased risk of MS, where a 1 SD increase in BMI conferred a $41 \%$ increase in the odds of MS. The researchers also found that a genetically determined change in BMI or an increase in BMI caused by other factors increases MS susceptibility. Despite all the findings of the literature, in the current controlled descriptive study, only for males, the difference between the BMI values of patients with MS and healthy controls was statistically significant $(\mathrm{p}=0.006)$. To investigate the association between BMI and the presence of MS, study participants were divided into two clusters according to the defined BMI threshold of $25 \mathrm{~kg} / \mathrm{m}^{2}$, which is the BMI cut-off value for being considered as overweight according to WHO. The result of the analysis showed that the presence of MS had no significant association with BMI.

When the relationship between MS and various anthropometric measurements was examined, it was determined that BMI and waist-to-hip ratio were not related to MS; however, waist-to-height ratio was found to have relation with MS. The anthropometric measurements that differed significantly between the patients with MS and healthy controls were as follows: for males, mid-upper arm circumference, waist-to-hip ratio, and $\mathrm{BMI}$; for females, hip circumference and waist-toheight ratio; for all participants, hip circumference, waist-tohip ratio, and waist-to-height ratio. The boxplots in Figure 2 graphically depict the difference in BMI, waist-to-hip ratio, and waist-to-height ratio in terms of the compared groups.

\section{Study Limitations}

Due to time constraints, the study could not be designed at MS onset. The results of this study are restricted to the lipid profiles and some anthropometric measurements collected from 392 participants who were all Turkish. Accordingly, it is important to note that the impact of ethnicity could not be observed in this study. For further studies, the sample size might be increased, and studies

Table 6. Comparison of the lipid profiles observed in multiple sclerosis-based studies in the literature

\begin{tabular}{|c|c|c|c|c|c|}
\hline \multirow{2}{*}{ Variable } & \multirow{2}{*}{ Study } & \multicolumn{2}{|c|}{ Healthy controls } & \multicolumn{2}{|l|}{ Patients with MS } \\
\hline & & Female & Male & Female & Male \\
\hline \multirow{4}{*}{ Triglycerides } & Current study & $111.63 \pm 66.69$ & $159.93 \pm 98.33$ & $123.28 \pm 69.70$ & $163.68 \pm 115.85$ \\
\hline & Jorissen et al. (14) & \multicolumn{2}{|l|}{$113.6 \pm 6.1$} & \multicolumn{2}{|l|}{$\begin{array}{l}136.6 \pm 17.8(\mathrm{RRMS}) \\
106.2 \pm 5.6(\mathrm{PMS})\end{array}$} \\
\hline & Çomoğlu et al. (11) & $101.0 \pm 54.1$ & $118.0 \pm 27.93$ & $241.0 \pm 121.5^{*}$ & $151.4 \pm 37.9^{\dagger}$ \\
\hline & Saka et al. (18) & \multicolumn{2}{|c|}{ (MS-female vs MS-male, $\mathrm{p}>0.05$ ) } & $75.6 \pm 30.9$ & $103.6 \pm 61.35$ \\
\hline \multirow{3}{*}{ TChol } & Current study & $190.59 \pm 45.20$ & $196.32 \pm 40.57$ & $191.29 \pm 42.05$ & $197.32 \pm 43.81$ \\
\hline & Saka et al. (18) & \multicolumn{2}{|c|}{ (MS-female vs MS-male, $\mathrm{p}>0.05$ ) } & $174.4 \pm 29.53$ & $159.1 \pm 34.71$ \\
\hline & Çomoğlu et al. (11) & $177.25 \pm 21.53$ & $172.5 \pm 35.38$ & $192.33 \pm 30.06$ & $206.4 \pm 20.43$ \\
\hline \multirow{4}{*}{ LDL } & Current study & $111.20 \pm 29.43$ & $121.20 \pm 36.50$ & $119.07 \pm 38.88$ & $125.55 \pm 41.14$ \\
\hline & Saka et al. (18) & \multicolumn{2}{|c|}{ (MS-female vs MS-male, $\mathrm{p}>0.05$ ) } & $110.9 \pm 28.16$ & $104.6 \pm 32.22$ \\
\hline & Jorissen et al. (14) & \multicolumn{2}{|l|}{$109.8 \pm 3.8$} & \multicolumn{2}{|l|}{$\begin{array}{l}96.6 \pm 4.8 \text { (RRMS) } \\
115.6 \pm 6.3 \text { (PMS) }\end{array}$} \\
\hline & Çomoğlu et al. (11) & $101.25 \pm 11.03$ & $87.5 \pm 23.87$ & $87.67 \pm 17.0$ & $118.6 \pm 19.03$ \\
\hline \multirow{4}{*}{ HDL } & Current study & $54.15 \pm 11.95$ & $46.30 \pm 12.68$ & $51.54 \pm 12.29$ & $43.29 \pm 8.87$ \\
\hline & Saka et al. (18) & \multicolumn{2}{|c|}{ (MS-female vs MS-male, $\mathrm{p}<0.001$ ) } & $48.4 \pm 11.41$ & $33.5 \pm 5.24$ \\
\hline & Jorissen et al. (14) & $61.0 \pm 1.7$ & & $\begin{array}{l}59.3 \pm 2.3(\mathrm{RRMS}) \\
60.8 \pm 3.5(\mathrm{PMS})\end{array}$ & \\
\hline & Çomoğlu et al. (11) & $51.75 \pm 14.22$ & $64.0 \pm 16.43$ & $51.67 \pm 8.04$ & $57.6 \pm 4.93$ \\
\hline
\end{tabular}


can be tried on patients from different ethnic groups. We tried to include all patients who satisfied the determined requirements in the study, and the resulting study group involved 134 female and 62 male patients. Therefore, the analyses could not be performed on a sex-matched design. Given that the majority of patients with MS were admitted from surrounding cities and it was difficult to access the medical records of these patients, the identification of subgroups could not be done. Moreover, because the current study was designed as a controlled, descriptive study, causality between the presence of MS and the associated variables could not be investigated. However, descriptive findings of this study can be used to construct a well-organized cohort study. Although Expanded Disability Status Scale (EDSS) scores were not included in the current study, in terms of the quantification of disability in MS, it would be informative to search for a relationship between anthropometric measures and the EDSS scores of people with MS in further studies.

\section{Conclusion}

The analyses and the results of this paper aimed to make contributions to the literature in terms of the recognition of MS by comparing lipid profiles and anthropometric measurements of people with and without MS. The results indicated that most of the anthropometric measurements of patients with MS significantly differed from healthy individuals, although no significant difference could be observed in terms of lipid profiles. Most of the findings of this study are consistent with the literature, suggesting that anthropometric changes in individuals should be followed regularly to prevent a possible risk of MS.

\section{Acknowledgement}

The authors would like to thank Department of Biochemistry at Karadeniz Technical University, Trabzon, Turkey for their valuable help in biochemical analysis of the samples.

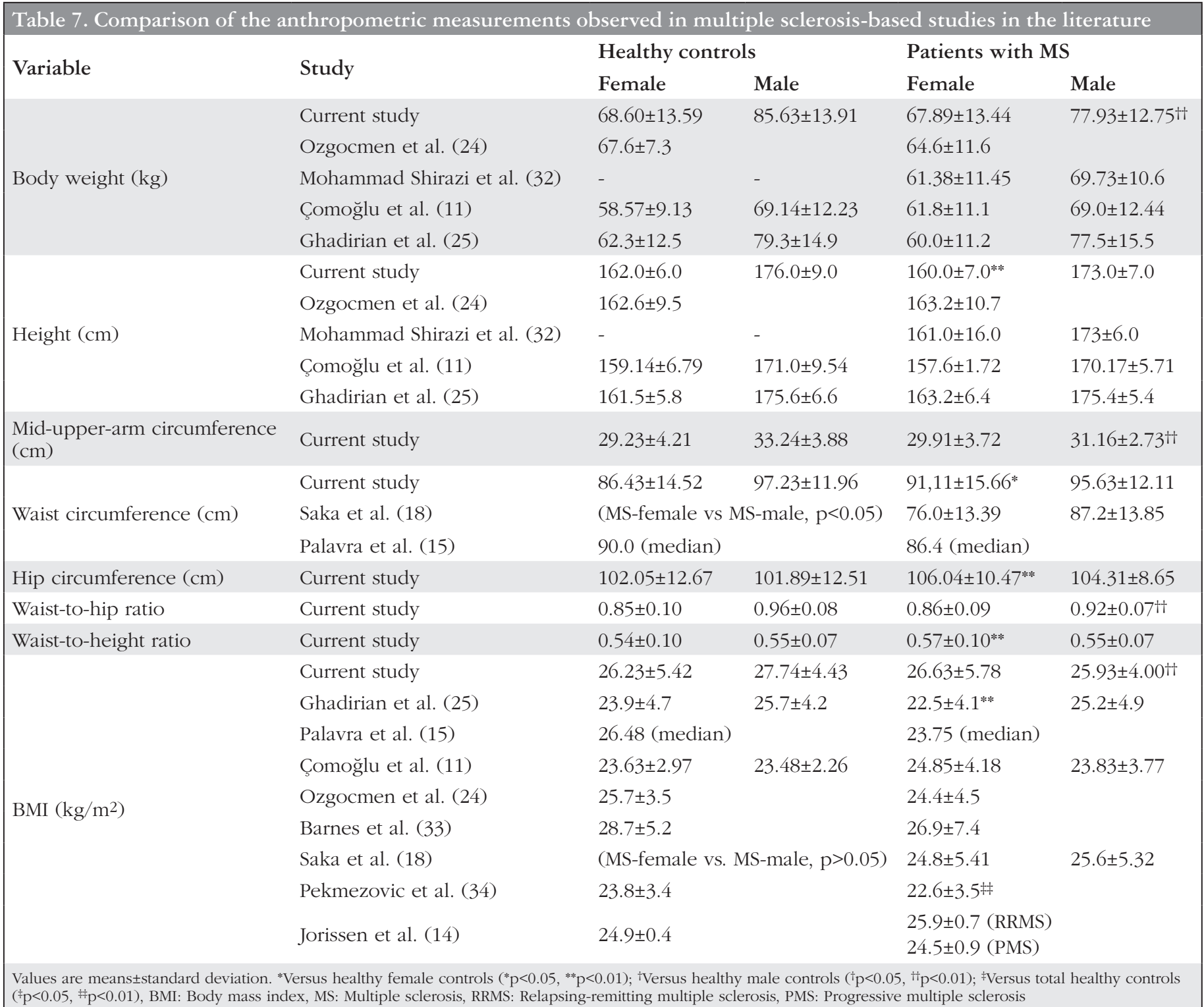



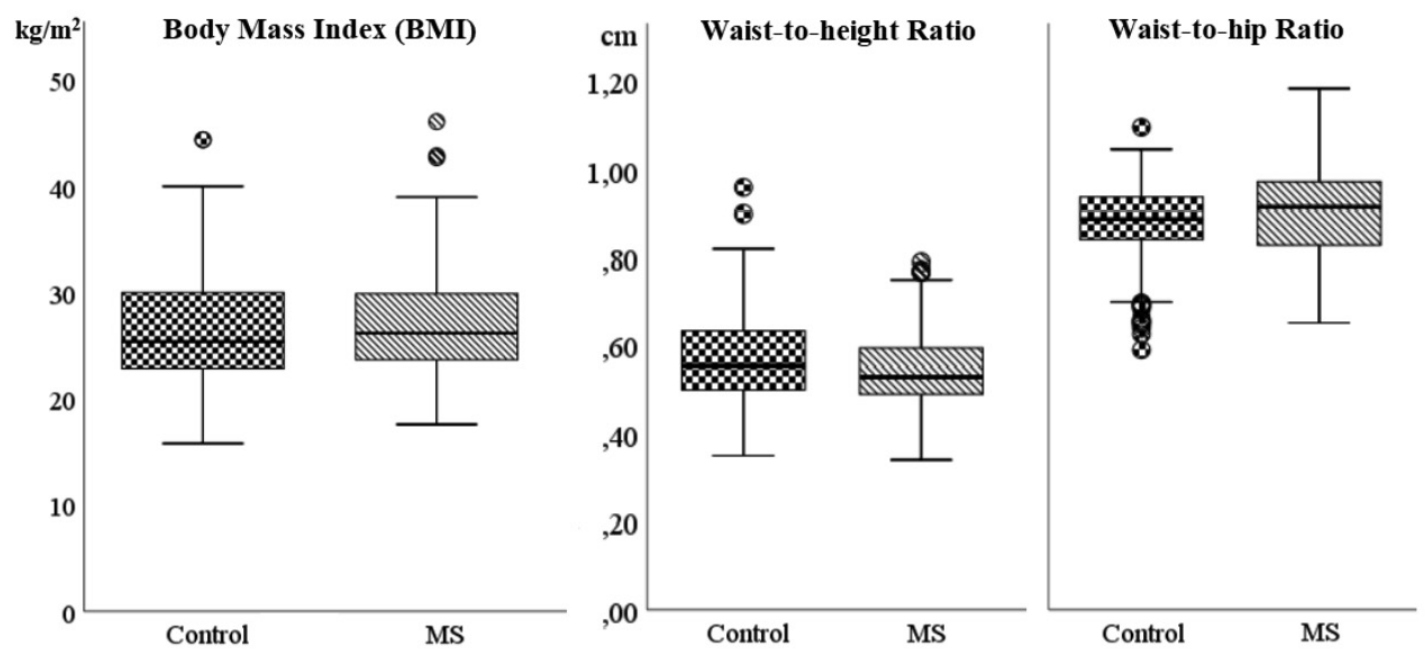

Figure 2. Comparison of the anthropometric measurements of the participants in the control and multiple sclerosis groups. Statistically significant differences were observed in terms of any of the considered measurements (each $\mathrm{p}<0.05$ )

MS: Multiple sclerosis

Ethics

Ethics Committee Approval: Approval for the study was obtained from the Ethics Committee of Karadeniz Technical University (decision no: 2016/82).

Informed Consent: Consent form was filled out by all participants.

Peer-review: Externally and internally peer-reviewed.

\section{Authorship Contributions}

Concept: G.D.A, A.A.M., H.T.B., Design: G.D.A., E.K., Data Collection or Processing: G.D.A, A.A.M., Analysis or Interpretation: E.K., G.D.A, A.A.M., H.T.B., Literature Search: G.D.A., E.K., Writing: G.D.A., E.K.

Conflict of Interest: No conflict of interest was declared by the authors.

Financial Disclosure: The authors declared that this study received no financial support.

\section{References}

1. World Health Organization (WHO). Neurological disorders: Public health challenges. Date accessed: December 13, 2019. Available from: https://www. who.int/mental_health/neurology/neurological_disorders_report_web.pdf

2. Weinshenker BC. Epidemiology of multiple sclerosis. Neurol Clin 1996;142:1-308.

3. Al-Omaishi J, Bashir R, Gendelman HE. The cellular immunology of multiple sclerosis. J Leukoc Biol 1999;65:444-452.

4. Dorrucci M, Longo B, Arpino C, Boros S, Rezza G. Combined antiretroviral therapy and the incidence of acquired immunodeficiency syndrome-related central nervous system diseases. Ann Neurol 2004;56:307-307.

5. Van Amerongen BM, Dijkstra C, Lips P PC. Multiple sclerosis and vitamin D: an update. Eur J Clin Nutr 2004;58:1095-1109.

6. Cree BAC. Multiple sclerosis. In: Brust JCM, ed. Current Diagnosis and Treatment in Neurology. New York: Lange Medical Books/McGraw-Hill Medical, 2007.

7. Pekcan G. Beslenme Durumunun Saptanması. 1st ed. Ankara: Klasmat Matbaacilık, 2008.

8. Hunt DR, Maslovitz A, Rowlands BJ, Brooks B. A simple nutrition screening procedure for hospital patients. J Am Diet Assoc 1985;85:332-335.
9. Kamalian N, Keesey RE, ZuRhein GM. Lateral hypothalamic demyelination and cachexia in a case of malignant multiple sclerosis. Neurology 1975;25:25-30.

10. Weinstock-Guttman B, Zivadinov R, Mahfooz N, et al. Serum lipid profiles are associated with disability and MRI outcomes in multiple sclerosis. J Neuroinflammation 2011;8:127.

11. Çomoğlu S, Yardimci S, Okçu Z. Body Fat Distribution and Plasma Lipid Profiles of Patients with Multiple Sclerosis. Turk J Med Sci 2004;34:43-48.

12. Newcombe J, Li H, Cuzner ML. Low density lipoprotein uptake by macrophages in multiple sclerosis plaques: implications for pathogenesis. Neuropathol Appl Neurobiol 1994;20:152-162.

13. Quintana FJ, Yeste A, Weiner HL, Covacu R. Lipids and lipid-reactive antibodies as biomarkers for multiple sclerosis. J Neuroimmunol 2012;248:53-57.

14. Jorissen W, Wouters E, Bogie JF, et al. Relapsing-remitting multiple sclerosis patients display an altered lipoprotein profile with dysfunctional HDL. Sci Rep 2017;7:1-14.

15. Palavra F, Marado D, Mascarenhas-Melo F, et al. New markers of early cardiovascular risk in multiple sclerosis patients: Oxidized-LDL correlates with clinical staging. Dis Markers 2013;34:341-348.

16. Navarro X, Segura R. Plasma lipids and their fatty acid composition in multiple sclerosis. Acta Neurol Scand 1988;78:152-157.

17. Dogan HO. Serum lipids and Lp-PLA2 activity in multiple sclerosis. Turkish J Biochem 2014;39:472-475.

18. Saka M, Saka M, Koseler E, et al. Nutritional status and anthropometric measurements of patients with multiple sclerosis. Saudi Med J 2012;33:160166.

19. World Health Organization (WHO). Global database on body mass index. Date accessed: November 15, 2018. Available from: http://apps.who.int/bmi/ index.jsp? introPage $=$ intro

20. World Health Organization (WHO). Waist circumference and waist-hip ratio. Date accessed: November 20, 2018. Availabe from: https://apps.who. int/iris/bitstream/handle/10665/44583/9789241501491_eng.pdf?ua $=1$

21. Ashwell M DHS. Six reasons why the waist-to-height ratio is a rapid and effective global indicator for health risks of obesity and how its use could simplify the international public health message on obesity. Int J Food Sci Nutr 2005;56:303-307.

22. Ahmed AM, Muawia M, Mohammed H, Elzein AM EA. Determination of lipid profile among Sudanese patients with prostate cancer in Khartoum State. Sch Acad J Pharm 2017;6:546-548.

23. Roubenoff R, Rall LC. Humoral Mediation of Changing Body Composition During Aging and Chronic Inflammation. Nutr Rev 1993;51:1-11. 
24. Ozgocmen S, Bulut S, Ilhan N, Gulkesen A, Ardicoglu O, Özkan Y. Vitamin $\mathrm{D}$ deficiency and reduced bone mineral density in multiple sclerosis: effect of ambulatory status and functional capacity. J Bone Miner Metab 2005;23:309313.

25. Ghadirian P, Jain M, Ducic S, Shatenstein B, Morisset R. Nutritional factors in the aetiology of multiple sclerosis: a case- control study in Montreal, Canada. Int J Epidemiol 1998;27:845-852.

26. Formica CA, Cosman F, Nieves J, Herbert J, Lindsay R. Reduced bone mass and fat-free mass in women with multiple sclerosis: Effects of ambulatory status and glucocorticoid use. Calcif Tissue Int 1997;61:129-133.

27. Munger KL, Chitnis T, Ascherio A. Body size and risk of MS in two cohorts of US women. Neurology 2009;73:1543-1550.

28. Khurana SR, Bamer AM, Turner AP, et al. The Prevalence of Overweight and Obesity in Veterans with Multiple Sclerosis. Am J Phys Med Rehabil 2009;88:83-91.

29. Hedström AK, Olsson T, Alfredsson L. High body mass index before age 20 is associated with increased risk for multiple sclerosis in both men and women. Mult Scler J 2012;18:1334-1336.
30. Munger KL, Bentzen J, Laursen B, et al. Childhood body mass index and multiple sclerosis risk: A long-term cohort study. Mult Scler J 2013;19:13231329.

31. Mokry LE, Ross S, Timpson NJ, et al. Obesity and Multiple Sclerosis: A Mendelian Randomization Study. PLoS Med 2016;13:1-16.

32. Mohammad Shirazi M, Taleban F, Ghafarpoor M. Macronutrients Intake in Iranian Multiple Sclerosis Patients. J Med Sci 2007;7:422-426.

33. Barnes MS, Bonham MP, Robson PJ, Strain JJ, Lowe-strong AS. Assessment of 25-hydroxyvitamin D and 1,25-dihydroxyvitamin D 3 concentrations in male and female multiple sclerosis patients and control volunteers. Mult Scler J 2007;13:670-672

34. Pekmezovic TD, Tepavcevic DBK, Mesaros ST, et al. Food and dietary patterns and multiple sclerosis: a case-control study in Belgrade (Serbia). Ital J Public Health 2012;6:81-87. 